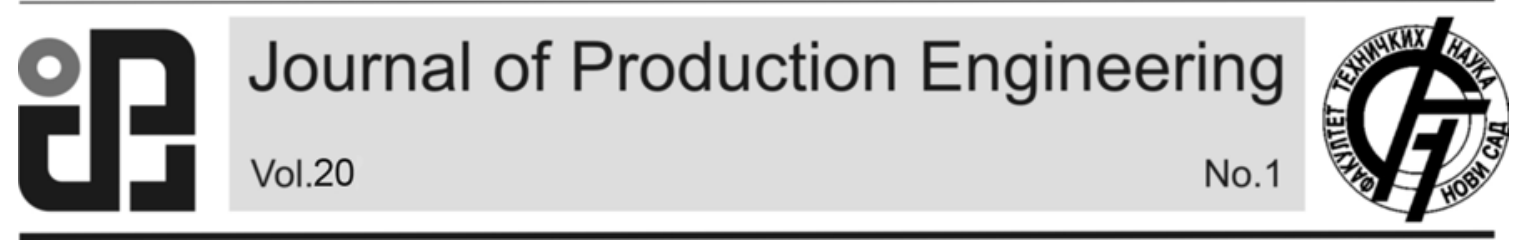

JPE (2017) Vol.20 (1)

Panda, S.B., Nayak, N.C., Mishra, A.

Original Scientific Paper

\title{
ENGINEERING POLYMERS IN AUTOMOBILE SEAT BELT LOCK APPLICATIONS: IT'S DEVELOPMENT, INVESTIGATION AND PERFORMANCE ANALYSIS
}

Received: 22 January 2017 / Accepted: 10 April 2017

\begin{abstract}
Almost all vehicles use seat belts for occupant's safety. The seat belt locking system consists of buckle assembly where the tongue plate enters the buckle assembly and locks automatically. The tongue plate is made by over molding injection process to a metal plate, which requires two distinct \& different process techniques to produce. In this research, the tongue plate is completely redesigned into a single piece injection molded part replacing the sheet metal part. The parts are produced using 'Delrin' and 'Nylon 6-GF 30\%' material separately by injection molding machine strictly following the International standard. Then, pertinent data were collected from mold flow analysis. The injection molding process is used to produce the component as a single part, which eliminates the sheet metal process, hence eliminating sheet metal die, process, post finishing operations, inventory etc. that reduces production cost, time and multiple numbers of parts. The tongue plate which is made by sheet metal and then polymer is being over molded into it, increases the process cost and also the chance of QC failure. This research concludes that the tongue plate may be produced as a single injection molded part with high accuracy, finish, strength and at a lower cost.
\end{abstract}

Key words: injection molding, mold flow analysis, composites, derlin, nylon, strength

Inženjerski polimeri primenjeni u automobilskoj bravi za pojaseve: njihov razvoj, istragživanje i analiza performansi. Skoro sva vozila koriste pojaseve za bezbednost putnika. Sistem zaključavanja pojaseva se sastoji od kopče pojasa gde jezičak pločice ulazi u sklop kopče i automatski se zaključava. I jezičak pločice je napravljen preko procesa oblikovanja na metalnu ploču, koja zahteva različite tehnike procesa proizvodnje. U ovom istraživanju, jezičak pločice je kompletno redizajniran $i$ u jednom komadu dobija se brizganjem $i$ zamenjuje presovan metalni deo. Delovi su proizvedeni upotrebom "delrin" i "Nilon 6-GF 30\%" materijala posebno na mašini za brizganje strogo poštujući međunarodne standarde. Zatim, su relevantn podaci prikupljeni iz analize protoka kalupa. Proces brizganja se koristi za proizvodnju komponenti kao jedan deo, koji eliminiše proces dobijanja iz lima, kalupe, završne operacije, inventar i sl što smanjuje troškove proizvodnje, vreme i višestruki broj delova. Jezčak pločice se sastoji od lima, preko koga se zatim uliva polimer, povećava troškove procesa i istovremeno je daje šansu za lošiji kvalitet. Ovo istraživanje zaključuje da se jezičak pločice može dobiti kao jedan deo ubrizgavanjem sa visokom preciznošću, završnim oblikom, odgovarajućom čvrstoćom i po nižoj ceni.

Ključne reči: brizganje, analiza protoka kalupa, kompozit, derlin, najlon, čvstoća

\section{INTRODUCTION}

Composite materials have been the better substitute for past few years ranging from everyday products to sophisticated engineering applications. At present high performance FRP, engineering plastics can be used to resist explosive impacts, automotive applications, windmill blades, industrial drive shafts, support beams of highway bridges and even paper making rollers. In certain applications, composites have replaced metals that resulted in saving both cost and weight. Particularly in automotive industries it has a great impact to save the fuel and subsequently increasing the performance.

The seat belt lock system consists of buckle assembly, tongue plate, knit fabric belt as shown in fig. 1. The tongue plate is made of steel and then over molded with polymer. It may so happen that the 'tongue plate' will be made of a single piece injection molded part, avoiding the sheet metal one, as many stages of operations could be eliminated such as the sheet metal production process, post finishing operation, surface treatment, inventory, etc. Moreover, the cost and time could be saved to a great extend also.

The objectives of this research work is to redesign and test using various CAE software to arrive at a single piece optimum design which could be produced as a single shot injection molded part. It should possess greater strength and practical application condition that finally could replace the existing part. As seat belt is meant for safety of the occupants during accidents, so special attention need to given towards achieving the strength and durability of the part.

Though there exist many polymers, engineering polymers, and high performance polymers (HPP), composites are widely used for automobile components where some of them also replace metals. In this research, we have taken four types of composite polymers for the discussed part aiming to replace the metal part.

\section{LITERATURE REVIEW}

From the existing literature, it is observed that 
research has been done on composites especially for automobile applications to replace metal components. High Performance polymers and engineering plastics is used to get the advantages such as corrosion resistance, better durability, high strength related to weight, design flexibility, dimensional stability etc.

Airbus Helicopters door fitting bracket is replaced by injection molded fiber-reinforced high performance polymer instead of aluminum, resulted a $40 \%$ reduction in weight and costs [1]. Researcher claims that injection molded glass fiber reinforced phenolic cylinder housings deliver the same performance as die cast aluminum components. They suggests that the composite casing delivers a weight reduction of up to $20 \%$ and manufacturing costs are approximately $10 \%$ lower. In addition, life cycle assessments demonstrate that the environmental impact of phenolic composite components over their entire lifetime is lower than that of aluminum alternatives [2]. Researcher [3] suggests an experimental vehicle engine featuring fiber-reinforced plastic (FRP) parts that could be lighter than aluminum. The engine parts, such as the cylinder casing, could shed up to $20 \%$ of its weight if it was made of fiberreinforced plastic rather than aluminum, without extra costs. The injection-molded parts could even be suitable for mass production. Fiber reinforced thermoplastic composites produced by injection molding process could be used for aircraft fuselage clips and brackets [4]. The less mass it carries around, power train has to work less, and with less fuel use. In other words, for every one percent reduction in mass, we gain half a percent in fuel economy [5]. Metal replacement saves weight from $35 \%$ - 50\%, eliminates material waste, reduces secondary operations which could be possible with single shot molding process. The above has advantages over simple loaded metal parts [6]. The brazed metal manifold components swapped out for V6 engines with a lightweight plastic part made from Nylon composites family that reduce weight and cost [7]. Automotive industry growth is being driven by the continued focus on lightweight construction, greater fuel efficiency and lower emissions, which is possible with carbon fiber reinforced plastic (CFRP) components [8]. High performance polymers (HPP) used to replace metals in the automotive industry that offers specific strengths, chemical resistance over metals. These materials could be low cost solutions to fuel tanks in past. High temperature capable HPP's (up to $300^{\circ} \mathrm{C}$ ) exhibit outstanding friction and wear performance, used in applications like replacing metal-polymer bushings with a full polymer solution [9]. Metal components could replace with lighter plastics such as fiber reinforced nylon family products that are durable in high-heat, harsh-chemical environments found in under hood applications [10]. Composite materials offer their light weighting benefits than steel and aluminum. Using glass-filled polypropylene (PP) one can replace a more expensive metal version of door module [11]. In an experiment, the feasibility of replacing the metal coil spring with the composite coil spring has been demonstrated [12]. Metal replacement to engine cover components using mineral-reinforced nylon resin and Zytel nylon resin for two cast-aluminum parts resulted in less weight and cost, without affecting function or performance [13]. Fibers are used to strengthen thermoplastic compounds, improving physical properties such as modulus, tensile strength, heat deflection temperature and dimensional stability. The fiber reinforced thermoplastics continues to replace metals for better performance. Well-known advantages of thermoplastics over metals include design freedom, reduced weight and corrosion resistance [14]. The study demonstrated that elliptical spring made of composites can be used for light and heavy truck suspension systems with substantial weight saving [15]. Another study find composites to have significant economic potential when considering the polymer composite body-in-white design against the mild-grade steel body that serves vehicle lightweighting and thereby improved fuel efficiency [16]. Palmyra fruit fiber reinforced composite has been developed and its strength has been tested for automobile applications [17]. A four-leaf steel spring at rear suspension system of light vehicles can be replaced with a composite made from fiberglass with epoxy resin [18].

\section{THEORY \& METHODOLOGY}

In this research, the tongue plate (Fig. 1) is completely redesigned to a single piece injection molded part replacing the sheet metal and subsequently its process, post finishing operations. It eliminates sheet metal die, post finishing, operation time, reducing the cost of the product, its weight and increasing the performance of the seat belt locking system. Various steps for manufacturing the lock are as follows:

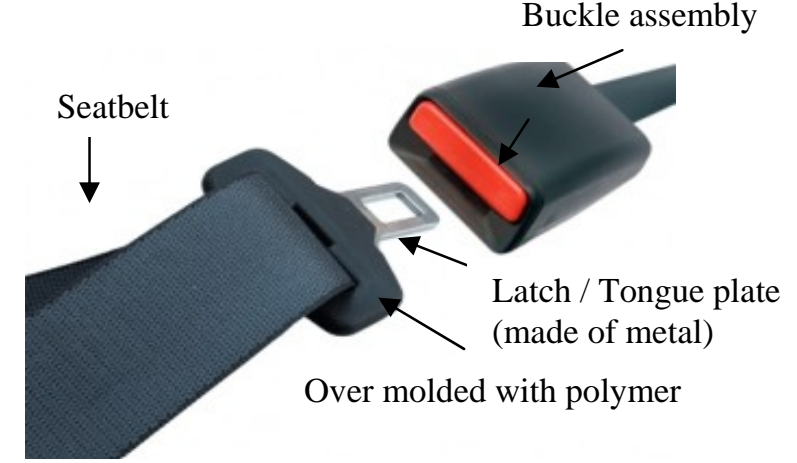

Fig. 1. Seat belt locking

\subsection{Part Design}

The tongue plate made up of sheet metal is to be prepared from polymer and over molded into it, made into a single part, which is designed \& validated by the ProE \& Mold Flow software. The part is first designed by ProE with all engineering validations such as tensile strength, load carrying capacity, etc.

The 3D CAD model is developed by ProE by considering all the dimensions with reference to the existing buckle assembly, and then little modifications incorporated to improve the strength at the load application areas, as shown in Fig. 2(a). Fig. 2(b) show detail drawings, being generated to check \& validate the 3D CAD model. 


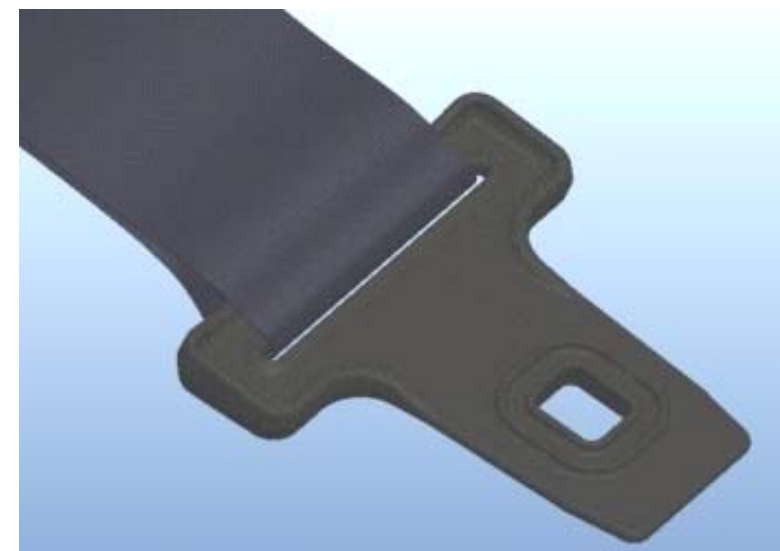

(a) 3D CAD model

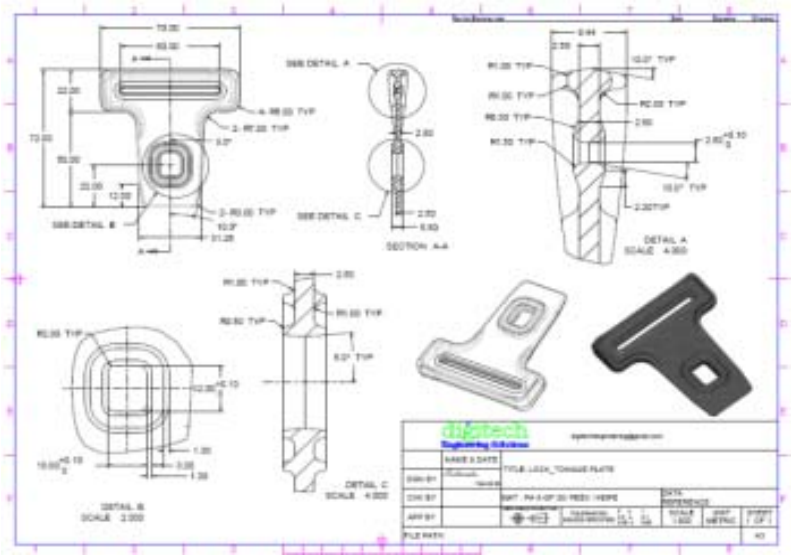

(b) 2D detail drawing

Fig. 2. Tongue plate

\subsection{Mold Design}

Injection mold is designed with Pro-E software and subsequently the tool drawings are created for mold manufacturing. CNC machining of core, cavity and other parts of the mold is being made to get the complete mold. Simultaneously an UTM sample piece is also being designed within the mold to carry out the tensile test of the part. This is being done to get the accurate results of the tongue plate part as the same processing parameters are involved for both the parts, as shown in Fig. 3 (a) \& (b). Fig. 3 (c) \& (d) shows the details of the mold prepared to manufacture seat belt lock.

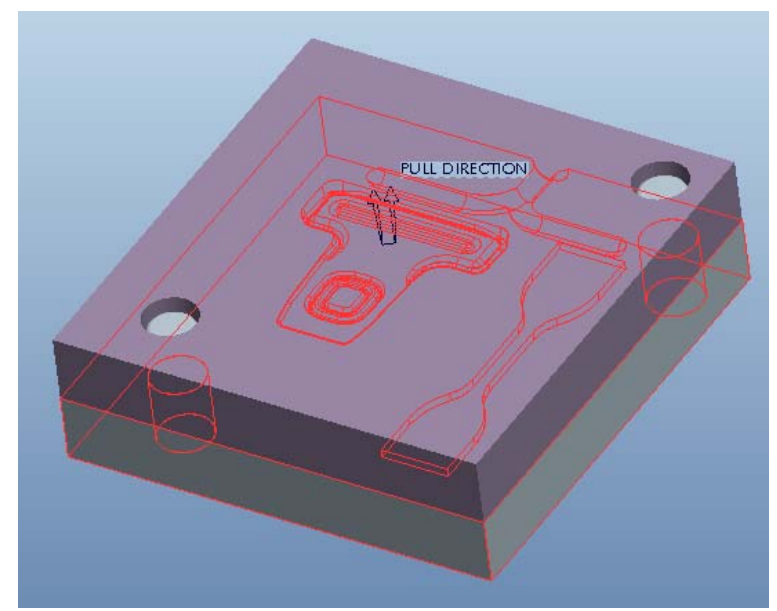

a) 3D Mold design assembly

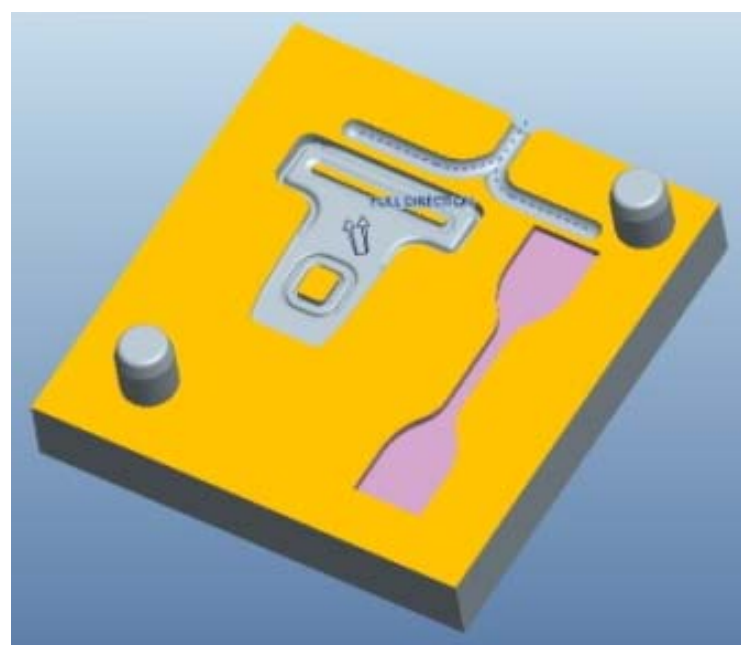

(b) 3D CAD of Cavity plate

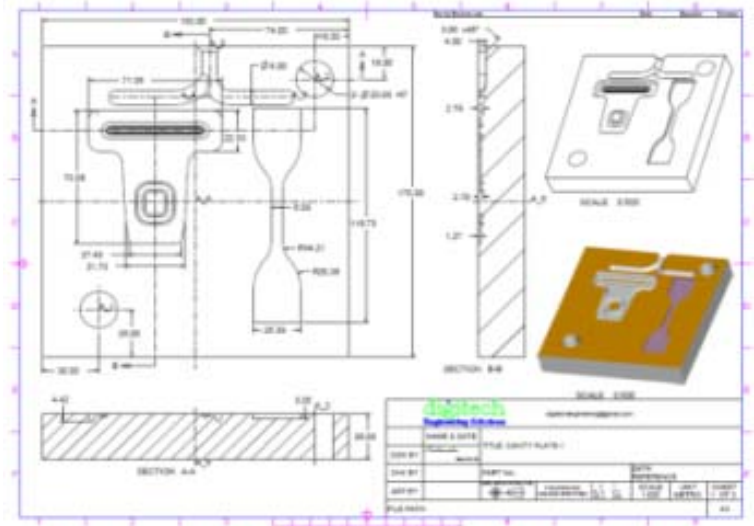

(c) Detail drawing of mold cavity plate

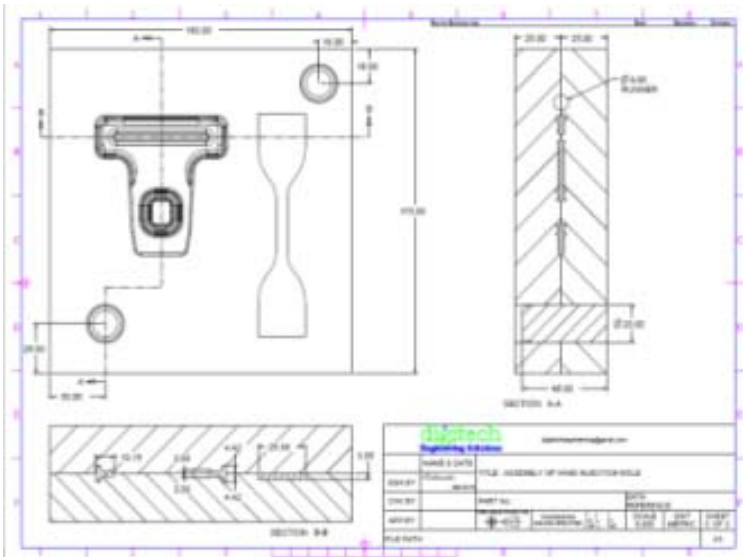

(d) 3D detail drawing of mold assembly Fig. 3. Mold design

\subsection{Analysis \& Optimization}

As new and advanced technology/software is available to validate the digital model prior to manufacturing, one should take advantage of that. While the part is being designed by the software, concurrently analysis followed by optimization being carried out to get the best engineered part. Thus, one can save much more cost \& time carrying out this project.

\subsubsection{Mold Floww Analysis}

As the part is going to be injection molded in a single shot, so it need to carry out the required 
analysis to predict the possible injection molding process difficulties in advance. The 'Mold Flow Plastic part advisor' is used here to validate injection molding process parameters. Many trials have been taken for gate location, and other parameters, and then the results for the mold flow analysis are shown in Fig. 4, as above.

(a) Flow Front Temperature: As shown in fig. 4 (a), the part shows with red in color has the maximum temperature during filling and gradually reduced to minimum at the blue color areas. So that we can decide the cooling circuits accordingly.

(b) Sink marks: As shown in fig. 4 (b), the part shows the sink mark severity in the color code red as maximum and blue gradually minimum, but there is no red color marking area. Though sink marks are present over at the extreme ends of the part, we need to give extra care to those areas by cooling first over to those portions then to other areas of the part.

(c) Weld lines: The most important criteria are how the polymer melts and supposed to join inside the mold during packing or filling. As shown in fig. 4 (c), the weld lines are in 2-3 places, which have been minimized by several attempts to gate location \& other technical parameters.

(d) Air traps: If the air in the mold cavity is being trapped, so there is the chance of voids present inside the part, which weakens the quality \& durability of the part during application. So it is needed to give air escape passages with respect to the air trap points, as shown in fig. 4(d).

Moreover, we can conclude that the mold flow analysis is done to a great extent to optimize the process parameters to design and validate the part for the injection molding process.

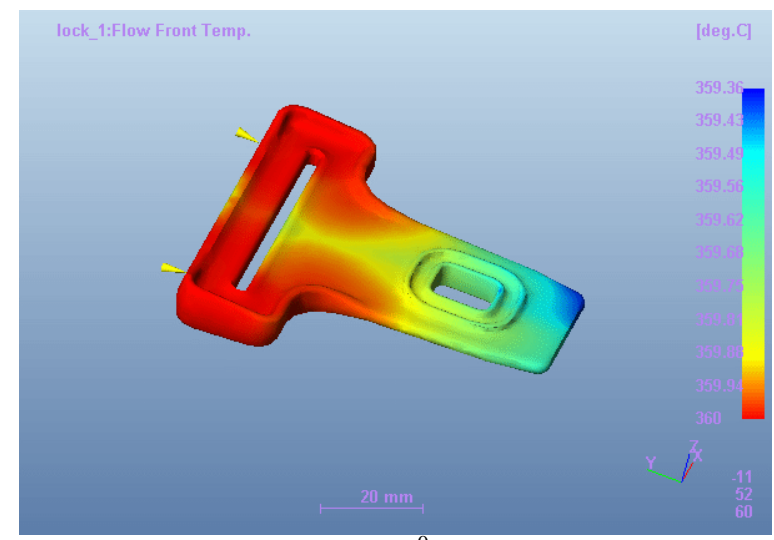

(a) Flow front temperature $\left({ }^{0} \mathrm{C}\right)$

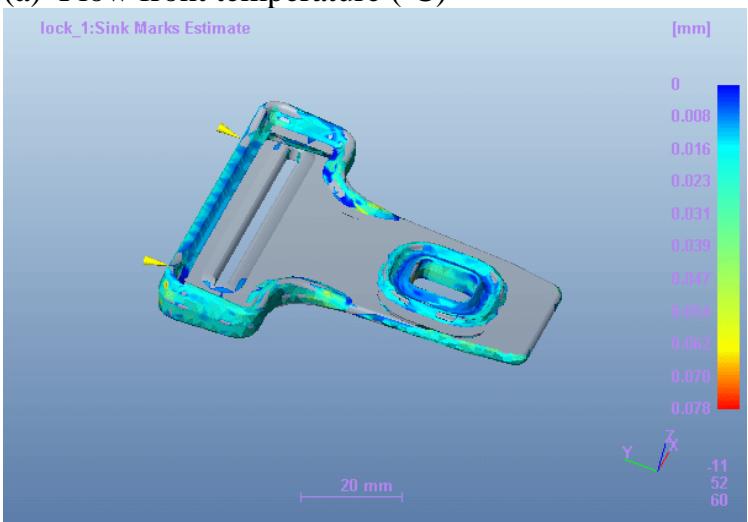

(b) Sink marks

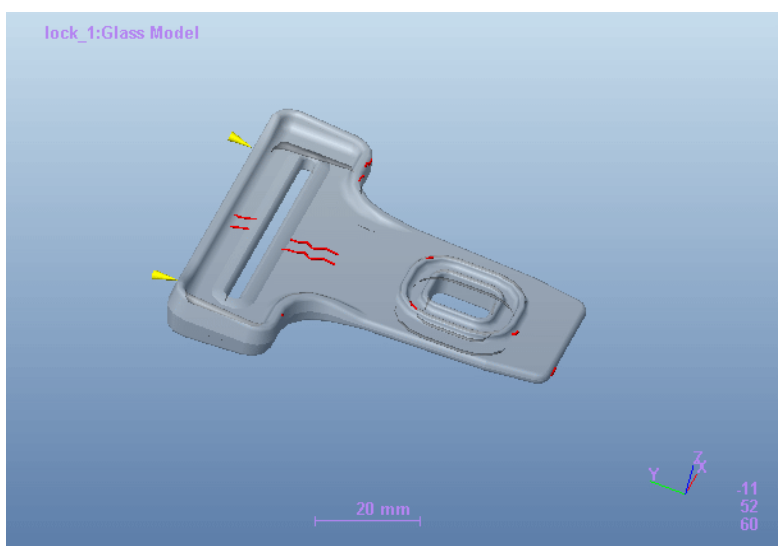

(c) Weld lines

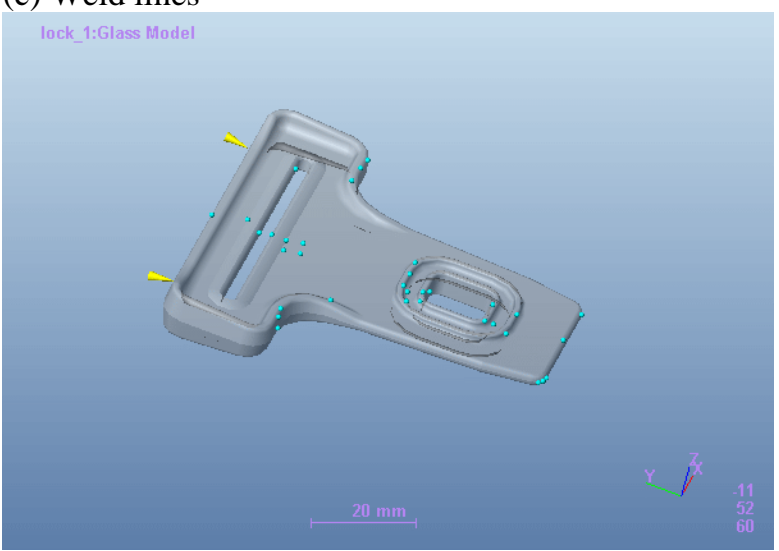

(d) Air traps

Fig. 4. Mold Flow analysis

\subsection{Mold Cavity Manufacturing}

Once the mold design is over followed by the mold flow analysis with satisfactory optimization of the part design \& mold design, then it is time to manufacture the mold. Out of 3D CAD data, CNC programming has been done for CNC machining operations to prepare the complete mould (Fig. 5).

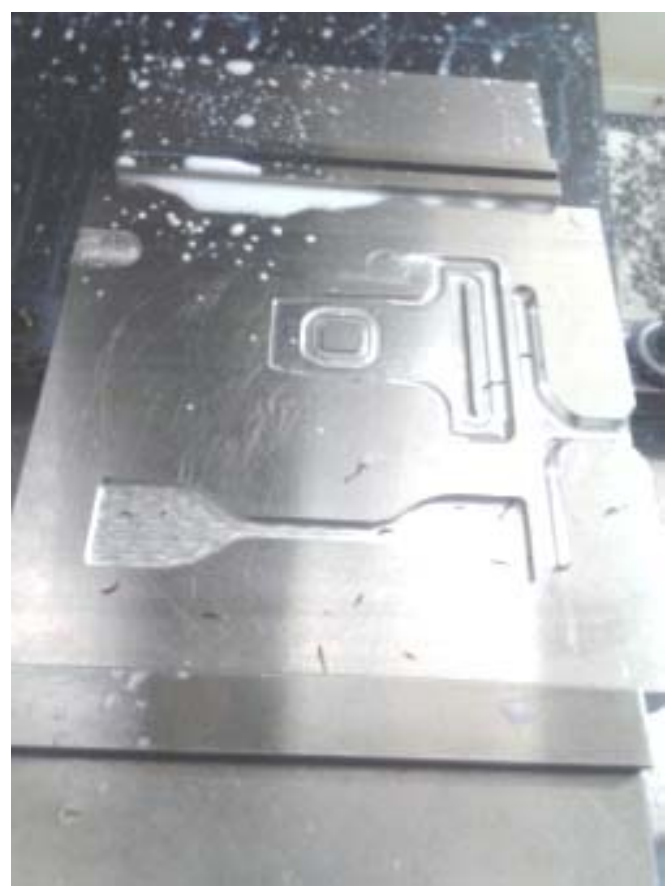

(a) Cavity machining 


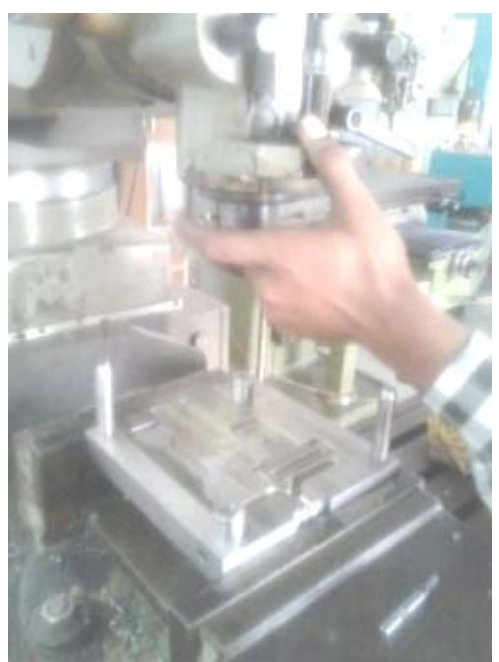

(b) Final machining

Fig. 5. Mold manufacturing

\subsection{Part Production}

To get the defect free parts out of the injection molding process we had carefully maintained the intended process parameters for the particular polymer materials as specified by the IS manufacturers (Fig. 6). The process parameters maintained for manufacturing seat lock from four different polymers are as provided in Table 1.

\begin{tabular}{|l|c|c|c|c|}
\hline $\begin{array}{l}\text { Process } \\
\text { parameters }\end{array}$ & $\begin{array}{c}\text { POM } \\
\text { GF 30 }\end{array}$ & $\begin{array}{c}\text { PA6 } \\
\text { GF 30 }\end{array}$ & $\begin{array}{c}\text { PA66 } \\
\text { GF 30 }\end{array}$ & $\begin{array}{c}\text { PP } \\
\text { GF 30 }\end{array}$ \\
\hline $\begin{array}{l}\text { Injection } \\
\text { Pressure(MPa) }\end{array}$ & 110 & 85 & 70 & 80 \\
\hline $\begin{array}{l}\text { Injection } \\
\text { Temp. }\left({ }^{0} \mathrm{C}\right)\end{array}$ & 210 & 260 & 280 & 240 \\
\hline $\begin{array}{l}\text { Melt Temp. } \\
\left({ }^{0} \mathrm{C}\right)\end{array}$ & 178 & 221 & 260 & 210 \\
\hline $\begin{array}{l}\text { Injection Time } \\
\text { (sec.) }\end{array}$ & 3 & 2 & 3 & 2 \\
\hline $\begin{array}{l}\text { Clamping } \\
\text { force (tone) }\end{array}$ & 105 & 80 & 65 & 75 \\
\hline $\begin{array}{l}\text { Cycle time } \\
\text { (sec.) }\end{array}$ & 5 & 4 & 5 & 5 \\
\hline
\end{tabular}

Table 1. Injection molding process parameters

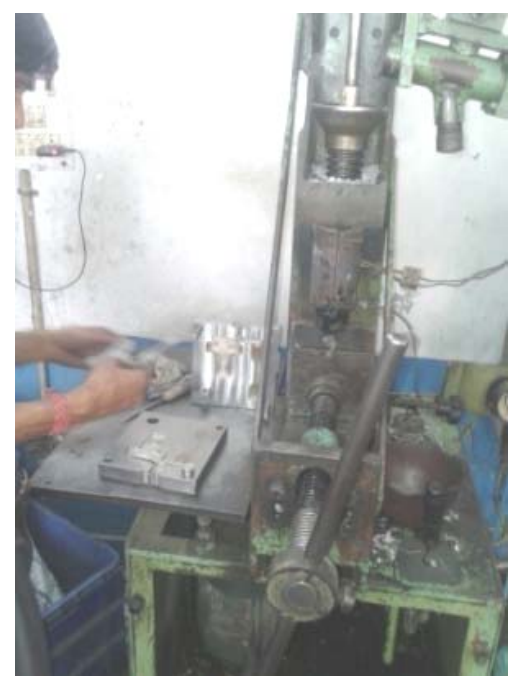

Fig. 6. Mold trial setup

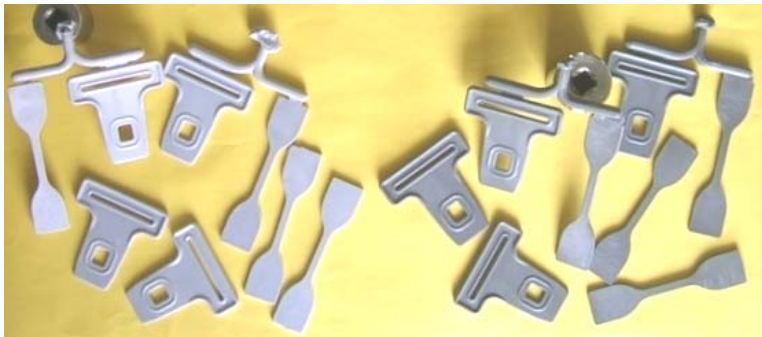

Fig. 7. Part production

The parts get produced using all the four materials separately by injection molding machine strictly following the data in Table 1, using 'mold flow analyses'.

\section{RESULTS \& DISCUSSION}

The seat lock which is made of four different engineering polymers has been undertaken different tests for the durability of the product as shown in Fig. 8.

Though all the composite polymers shown satisfactory results, but PA6GF30 has better results as compared to all the rest 3 types of polymers in all respects.

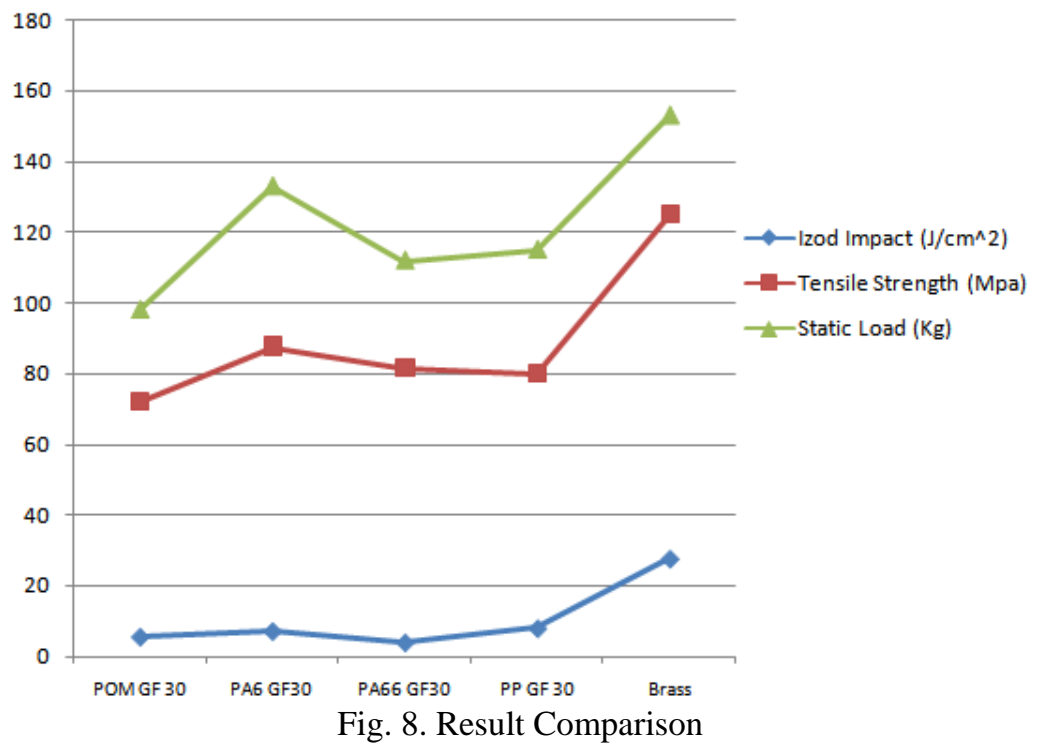




\section{CONCLUSION\&SCOPE OF FUTURE WORK}

The tongue plate which is made of complete injection molding process has significant result that has replaced the existing metal with polymer over-molded part. The above eliminates the sheet metal process \& cost for finishing the product. It also reduces the chances of rejection of QC failure using optimization technique. This also reduces the post finishing operations on sheet metal press part. Moreover, this research manufactures and tests the tongue plate which has been produced as injection molded component as a single finished part with same strength as earlier seat locking system.

\section{REFERENCES}

[1] Wolf, C. 40\% weight reduction with carbon fiber part, Reinforced Plastics, Vol. 59, No. 6, pp. 258259, 2015.

[2] Austin, T., Morgan, F., Keyser, H.D., Caliendo, H., and Farish, M. Composite future for cylinder housings, Reinforced Plastics, Vol. 59, No. 4, pp. 152-153, 2015.

[3] Berg, L.F., Koch, B. and Niesing, B. FRP engine parts could reduce vehicle weight, Reinforced Plastics, Vol. 59, No. 4, pp. 154-163, 2015.

[4] Gardiner, G., Herr, T. and Kneath, T. Overmolding expands PEEK's range in composites, Composites World, Vol. 1, No. 7, pp. 19-21.

[5] Murray, C. Carbon Fibers Spearhead Automotive Light weighting Effort, Science Journals: Design news, Vol. 70, No. 7, pp. 42-42, 2015.

[6] Eby, J., Schenk, G., Labatut, V. and Schenk, G. Tweed and Aerolia validate thermoplastic composite replacement for complex-shape metallic, Reinforced Plastics, Vol. 21, No. 3, pp. 32-38, 2014.

[7] Hopperton, L., Granowicz, P. and Terrell, T. Plastic manifold to feature on Ford's latest V6 engine, Eureka Engineering Design, Vol. 12, No. 1, pp. 12-19, 2014.

[8] Jacob, A. and Gray, N. Carbon fibre and cars 2013 in review, Reinforced Plastics, Vol. 58, No. 1, pp. 18-19, 2014.

[9] Gurchinoff, S., Fish, D. and Stern, B. High Performance Polymers for Small Engine Applications, Engineering Design, Vol. 11, No. 3, pp. 52-69, 2013.

[10] LeGault, M., Conkey, J., Schlicker, S., Newill, B. and Conkey, S. High-temp Thermoplastics: Higher expectation, Composite world, Vol. 18, No. 5, pp. 26-28, 2012.
[11] Stewart, R. and Bowland, C. Automotive composites offer lighter solutions, Reinforced Plastics, Vol. 54, No. 2, pp 22-28, 2010.

[12] Budan, D.A. and Manjunatha, T.S. Investigation on the Feasibility of Composite Coil Spring for Automotive Applications, International Journal of Mechanical, Aerospace, Industrial, Mechatronic and Manufacturing Engineering, Vol. 4, No. 10, pp. 1035-1039, 2010.

[13] Ederlan, F. and Ghosn, C. Nissan replaces metal engine covers, Reinforced Plastics, Vol. 52, No. 6, pp. 4-13, 2008.

[14] Markarian, J., Eckert, C., Hoppe, K. and Watkins, C. Strengthening compounds through fiber reinforcement, Reinforced Plastics, Vol. 51, No. 2, pp. 36-39, 2007.

[15] Goudah, G., Mahdi, E., Talib, A.R., Mokhtar, A.S. and Yunuset R. Automobile Compression Composite Elliptic Spring, International Journal of Engineering and Technology, Vol. 3, No.2, pp. 139-147, 2006.

[16] Fuchs, E.R.H., Field, F.R., Roth, R. and Kirchain, R.E. Strategic materials selection in the automobile body: Economic opportunities for polymer composite design, Composites Science and Technology, Vol. 68, No. 9, pp. 1989-2002, 2005.

[17] Nayak N. C. and Mishra A, Development and mechanical characterization of Palmyra fruit fibre reinforced epoxy composites, Journal of Production Engineering, Vol. 16. No. 2, pp. 6972, 2013.

[18] Mahmood M.S. and Rezaei, D. Analysis and optimization of a composite leaf spring, Composite Structures, Vol. 21, No. 2, pp. 23-29, 2003.

Authors: Sudhanshu B. Panda, Research Scholar in Mechanical Engineering Department, Indira Gandhi Institute of Technology (An Autonomous Institute of Govt. of Odisha), Sarang, India - 759146.

Ph D Narayan C. Nayak, Reader in Mechanical Engineering Department, Indira Gandhi Institute of Technology (An Autonomous Institute of Govt. of Odisha), Sarang, India - 759146. (Corresponding Author)

Ph D Antaryami Mishra, Professor in Mechanical Engineering Department, Indira Gandhi Institute of Technology (An Autonomous Institute of Govt. of Odisha), Sarang, India - 759146.

E-mail: sudhanshu.panda@gmail.com nayak.iem@gmail.com igit.antaryami@gmail.com 